\title{
TRANSFORMASI FUNGSI JALAN UMUM SEBAGAI RUANG PUBLIK BAGI MASYARAKAT URBAN Studi Kasus: Bundaran Lungsir Bandar Lampung
}

\author{
M. Shubhi Yuda Wibawa ${ }^{1}$; Yunita Kesuma ${ }^{2}$ \\ ${ }^{1,2}$ Program Studi Arsitektur, Jurusan Teknik Sipil, Fakultas Teknik, \\ Universitas Lampung, J1. Soemantri Brojonegoro No.1, Bandar Lampung \\ Email: shubhiyuda@gmail.com; yunitakesuma.unila@gmail.com
}

\begin{abstract}
Intisari
Jalan sejatinya berfungsi sebagai prasarana transportasi darat yang menghubungkan suatu tempat ke tempat lain. Sementara itu Jalan Umum adalah jalan yang diperuntukkan bagi lalu lintas umum dan untuk kepentingan umum. Namun seiring berkembangnya suatu kota dan bertambahnya jumlah penduduk, fungsi jalan umum yang semula hanya sebagai prasarana lalu lintas mengalami transformasi fungsi. Jalan Umum yang semula hanya mempunya fungsi tunggal berubah menjadi suatu tempat yang dapat berfungsi ganda. Jalan Umum digunakan sebagai tempat efektif untuk menyebar informasi melalui konvoi dan pawai. selain itu, digunakan juga sebagai media sosialisasi pasif untuk mencitrakan identitas suatu kota kepada pengguna jalan dengan cara mendesain ruang-ruang pembentuknya yaitu melalui desain monumen dan atau landscape yang diletakkan pada median jalan atau bundaran. Jalan umum di suatu kota khususnya pada kota-kota besar belakangan ini banyak digunakan untuk aktivitas sosial masyarakat seperti perayaan peristiwa penting, pesta rakyat, olah raga massal, dan aktivitas sejenis yang dilakukan pada waktu-waktu tertentu. Namun seiring mendesaknya kebutuhan masyarakat terhadap keberadaan ruang publik dan sarana rekreatif non komersil, Jalan Umum dijadikan ruang publik tanpa mengenal waktu atau momen tertentu. Salah satu contohnya adalah pada Jalan Umum di sekitar Bundaran Lungsir Bandar Lampung. Jalan umum di sekitar Bundaran Lungsir memiliki suasana spasial potensial yang mudah dikenali yaitu terdapat masjid besar bersejarah, monumen Patung Pengantin, pandangan langsung ke arah laut dan dimensi jalan yang sangat lebar. Penelitian ini akan menganalisa tentang bagaimana jalan umum di sekitar Bundaran Lungsir bertransformasi menjadi ruang publik yang sangat diminati di Kota Bandar Lampung. Penelitian ini akan menganalisa asal muasal dan pengaruh-pengaruh yang menyebabkan terjadinya transformasi pada jalan umum di sekitar Bundaran Lungsir. Dengan menggunakan metoda sinkronik - diakronik penelitian ini akan menghasilkan ilustrasi kronologis tentang proses terjadinya transformasi fungsi jalan umum menjadi ruang publik dengan memetakan waktu dibangunnya fasilitas fisik dan spasial yang membentuk citra visual ruas jalan umum di sekitar Bundaran Lungsir. Selain itu penelitian ini juga akan dilakukan secara kualitatif - eksploratif dengan mewawancarai pengguna jalan umum untuk mengetahui motivasi masyarakat yang datang dan menggunakan sebagai ruang publik.
\end{abstract}

Kata kunci: Transformasi, Fungsi Jalan, Ruang Publik, Bundaran Lungsir Lampung

\begin{abstract}
Road essentially serves as a land transport infrastructure that links one place to another, while main road is the road that intended for the public and for the public interest. But along with the development of a city and the increase of population, the original function of main roads as a traffic infrastructure undergoes a function's transformation. Main roads are used as an effective space to spread information through the convoy, March and parade. Furthermore, main roads are used as well as a passive media to imaged identity of the city for public or road users by designing the forming spaces through monuments or landscape that is placed on the median of the road or roundabout. These days, Main roads in a city, especially in big cities, widely used for social activities such as the celebration of a notable event, the people's party, mass sports, and similar activities are carried out at certain times. However, along with the increasing gap between the numbers of public space's availability in the city and the urgency of people's needs for public space and non-commercial recreational facilities, Main Road used as a public space without time or a particular moment. One example is the Main Road around Lungsir roundabout in Bandar Lampung. Main roads around the Lungsir roundabout have the potential spatial atmosphere that is easily recognizable; there are historic great mosques, and monument of Lampungnese Bride, wide dimensions of road and view of Lampung Bay. For this few years, this main road has transform not only serve as its essential functions, but also used as a place where people gathered to hang out, contemplate, relaxations and play, completed with temporary street vendors as its facilities to fill people's needs. This study will analyze how the main roads around the Lungsir roundabout transformed into a popular public space in the
\end{abstract}


city of Bandar Lampung. This study will analyze the origins and influences that lead to the transformation of the main roads around the Lungsir roundabout. Applying the synchronic - diachronic methode, this study will generate a chronological illustration of the transformation process of main road's function into public space by mapping the construction time of spatial and physical facilities that create the visual image of public main roads around the Lungsir roundabout. Furthermore, this study will also be conducted qualitatively - explorative interviewing general road users to know the motivation of the people who come and use it as a public space.

Keywords: Transformation, function of Street Space, Public Space, Bundaran Lungsir, Lampung.

\section{PENDAhuluan}

Jalan sejatinya berfungsi sebagai prasarana transportasi darat yang menghubungkan suatu tempat ke tempat lain. Jalan Umum adalah jalan yang diperuntukkan bagi lalu lintas umum dan untuk kepentingan umum. Jalan Umum digunakan sebagai tempat efektif untuk menyebar informasi melalui konvoi, pawai, juga sebagai media sosialisasi pasif untuk mencitrakan identitas suatu kota kepada pengguna jalan dengan cara mendesain ruang-ruang pembentuknya melalui desain monumen dan atau landscape yang diletakkan pada median jalan atau bundaran.

Seiring berkembangnya suatu kota dan bertambahnya jumlah penduduk serta semakin mendesaknya kebutuhan masyarakat terhadap keberadaan ruang publik dan sarana rekreatif non komersil, fungsi jalan umum yang semula hanya sebagai prasarana lalu lintas mengalami transformasi fungsi. Jalan Umum dijadikan ruang publik tanpa mengenal waktu atau momen tertentu.

Wilayah Bundaran Lungsir sejatinya adalah ruang jalan yang menjadi jalur sirkulasi utama kota Bandar Lampung. Namun pada malam hari, terutama saat akhir pekan, ruang jalan tersebut mendapat tambahan fungsi yaitu fungsi/kegiatan wisata. Banyak warga yang menghabiskan waktu, menikmati malamnya dengan berkumpul, berinteraksi dan berwisata di wilayah Bundaran Lungsir.

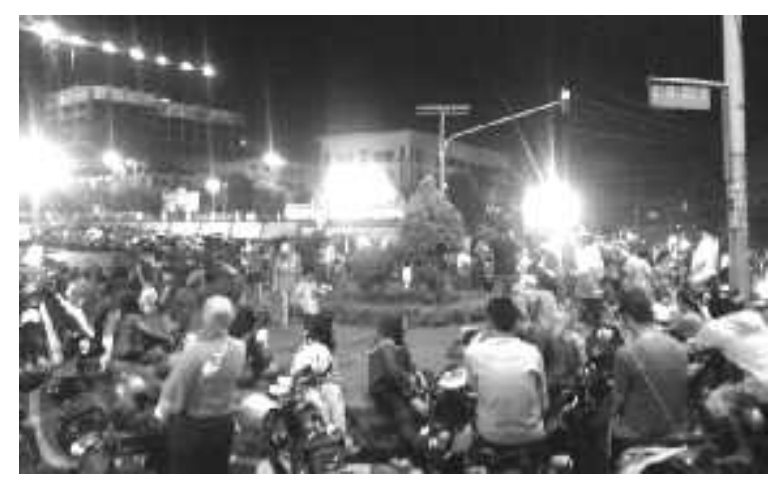

Gambar.1 Suasana malam hari di Bundaran Lungsir

(Sumber : dokumentasi penulis, 2016)

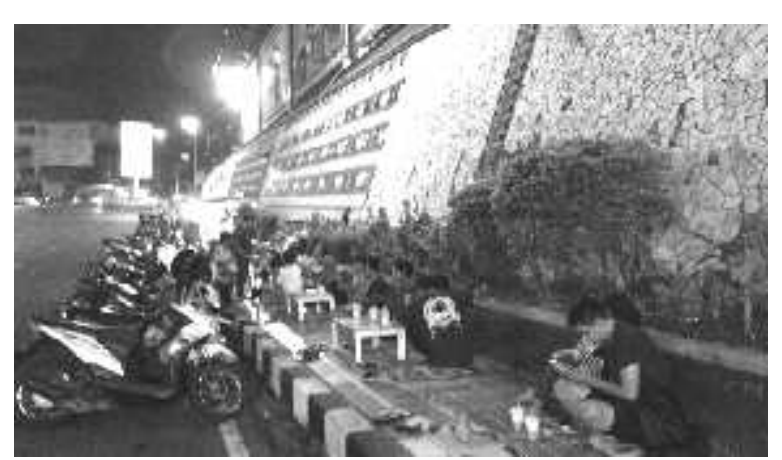

Gambar.2 Trotoar dimanfaatkan sebagai tempat berjualan, areaa santap dan bersantai

(Sumber: saibumi.com)

Bundaran Lungsir yang merupakan wilayah pertemuan antara dua jalan utama di kota Bandar Lampung, yaitu Jalan Dr. Soesilo dan Jalan Diponegoro, merupakan salah satu titik simpul sirkulasi jalan utama, Bundaran Lungsir menjadi simpul penting dalam linkage system jalan kota untuk memberi gambaran karakter dan ciri kota Bandar Lampung secara umum. Selain dimensi ruangnya yang besar, terdapat beberapa bangunan penting serta landmark kota sebagai elemen fisik pada wilayah Bundaran Lungsir, yang menjadikannya unik dan memiliki karakter khas.

Jalan umum di sekitar Bundaran Lungsir memiliki suasana spasial potensial yang mudah dikenali yaitu terdapat masjid besar bersejarah, monumen Patung Pengantin, pandangan langsung ke arah laut dan dimensi jalan yang sangat lebar.

\section{ISI PENELITIAN}

\subsection{Metode Penelitian}

Penelitian ini akan menganalisa tentang bagaimana jalan umum di sekitar Bundaran Lungsir bertransformasi menjadi ruang publik yang sangat diminati di Kota Bandar Lampung. Penelitian ini akan menganalisa asal muasal dan pengaruhpengaruh yang menyebabkan terjadinya transformasi pada jalan umum di sekitar Bundaran Lungsir. Dengan menggunakan metoda sinkronik - diakronik penelitian ini akan menghasilkan ilustrasi kronologis tentang proses terjadinya transformasi fungsi jalan umum menjadi ruang publik dengan memetakan waktu dibangunnya fasilitas fisik dan spasial yang 
membentuk citra visual ruas jalan umum di sekitar Bundaran Lungsir. Selain itu penelitian ini juga akan dilakukan secara kualitatif - eksploratif dengan mewawancarai pengguna jalan umum untuk mengetahui motivasi masyarakat yang datang dan menggunakan sebagai ruang publik.

\subsection{Masjid Agung Al Furqan,}

yang merupakan salah satu masjid terbesar di Lampung, sejarah pembangunan masjid ini berawal dari prakarsa Presiden Indonesia pertama, Ir. Soekarno pada tahun 1951. Pembangunan fisik masjid sendiri baru dimulai pada tahun 1958 dengan luas bangunan $20 \times 25$ $\mathrm{m}$. Selanjutnya pembangunan tahan ke dua dilaksanakan pada tahun 1970 yang diketuai oleh H. Zainal Abidin Pagar Alam selaku Gubernur Lampung pada saat itu. Renovasi bangunan masjid kembali dilakukan pada tahun 1998 yang dilakukan oleh Gubernur Lampung, Poedjono Pranyoto dan diketuai oleh Drs. H. Suwardi Ramli.

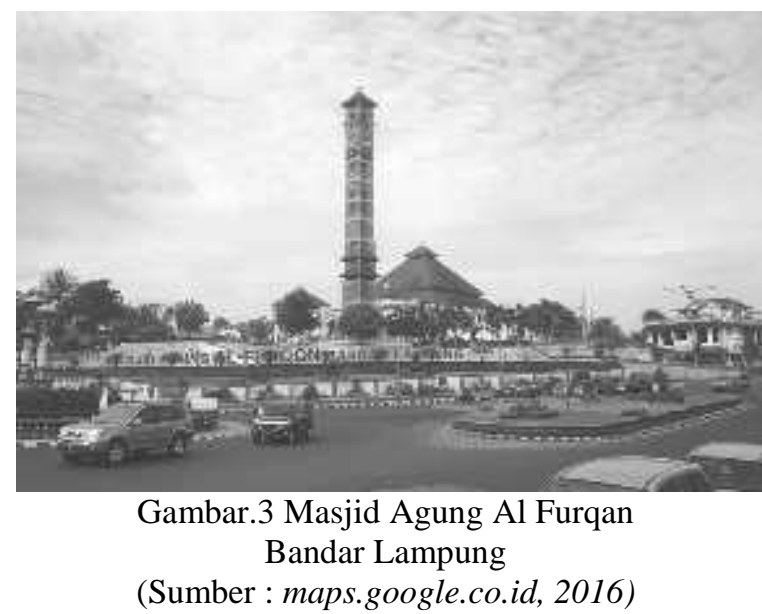

\subsection{Patung Pengantin Saibatin;}

Monumen budaya berupa monumen patung pengantin adat Pepadun yang merupakan salah satu dari 2 suku adat Lampung pada bundaran, serta taman-taman yang membentuk alur pergerakan kendaraan di tengah persimpangan dua jalan utama tersebut. Patung Pengantin ini menjadi ikon/landmark kawasan Bundaran Lungsir. Pembangunan monumen budaya ini bertujuan untuk menunjung adat istiadat dan budaya Lampung, serta merupakan penghargaan dan bentuk kepedulian terhadap masyarakat pribumi.

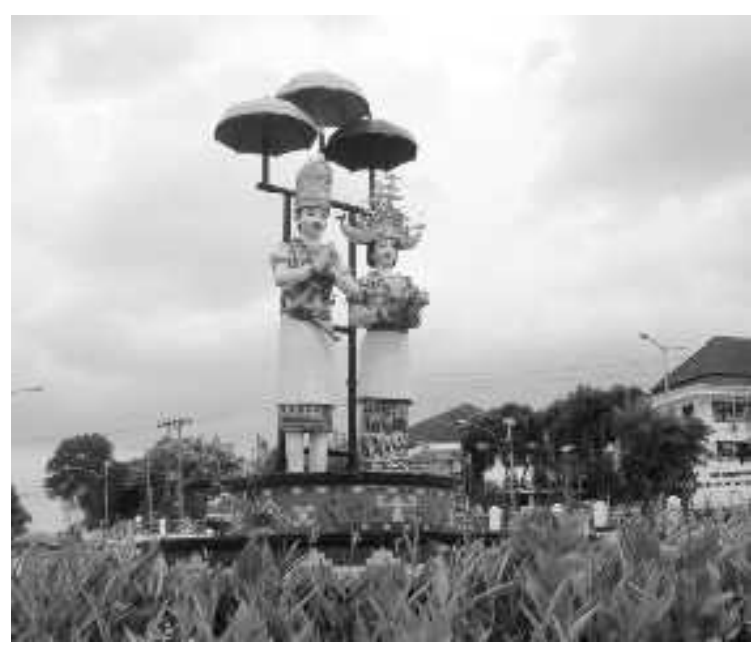

Gambar.4 Monumen Budaya Patung Pengantin Adat Pepadun (Sumber : wikipedia, 2016)

2.4 View langsung ke Teluk Lampung,

yang bisa dinikmati saat cuaca cerah, sehingga menambah keindahan dan daya tarik visual.

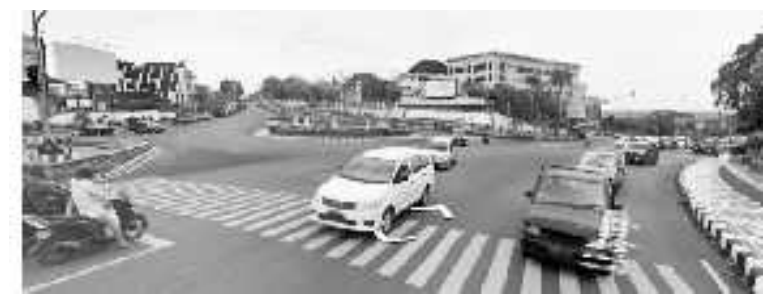

Gambar.5 Bundaran Lungsir dengan view Teluk Lampung di kejauhan

(Sumber : maps.google.co.id, 2016)

Elemen fisik sekitar Bundaran Lungsir membentuk karakter visual kawasan yang kemudian menjadi ciri khas dari wilayah tersebut. Atribut yang menunjukkan ciri khas tersebut dapat diamati dari keragaman bentuk dan fungsi bangunan/massa solid yang berada di sepanjang sisi jalan wilayah Bundaran Lungsir ini dimana terdapat komplek Kantor Pemerintah Kota Bandar Lampung serta Masjid Al Furqon.

\section{ANALISIS DAN PEMBAHASAN}

\subsection{Analisis}

\subsubsection{Bundaran Lungsir Sebagai Ruang Publik}

Pola tata ruang pada wilayah ini secara tekstural dapat diklasifikasikan sebagai susunan kawasan yang bersifat heterogen, dimana terdapat dua (atau lebih) pola berbenturan. Meskipun tidak secara langsung dibatasi oleh keteraturan massa yang membentuk pola ruang, struktur fisik wilayah bundaran lungsir ini dibentuk oleh kondisi topografi yang cukup terjal pada sisi sepanjang jalan, sehingga elemen fisik/obyek pada ruang jalan maupun di wilayah sekitarnya dapat dengan mudah dilihat dan diamati oleh pengguna jalan. 
Skala dimensi ruang yang besar pada wilayah Bundaran Lungsir ini juga mengaburkan kesan meruang yang dilihat dari perbandingan antara lebar ruang jalan dan ketinggian elemen pelingkupnya. Kurangnya kesan meruang pada wilayah ini menjadikannnya seperti ruang terbuka yang besar sehingga sifatnya menjadi sangat publik.

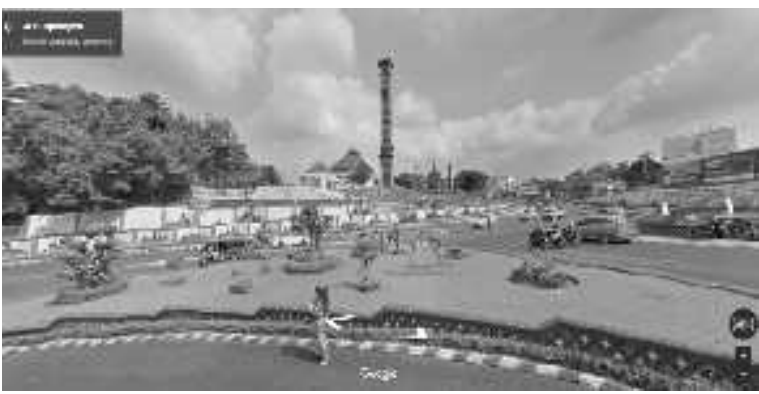

Gambar.6 Bentuk taman di Bundaran Lungsir sebagai pengarah pergerakan

(Sumber: maps.googe.co.id, 2016)

Salah satu elemen fisik yang menjadi ikon sekaligus landmark di wilayah Bundaran Lungsir ini yaitu monumen budaya patung pengantin serta taman-taman yang melingkupinya. Wajah Bundaran Lungsir pada dasarnya dibentuk atas sistem pergerakan dalam jalur jalan/path. Bentukan tamantaman yang ada di tengah wilayah ini serta karakteristik dinding ruang jalan yang melingkupinya tidak hanya berfungsi untuk memperindah kawasan tapi juga memberi arah dan tujuan yang jelas terhadap pergerakan sehingga memberi identitas yang baik.

\subsubsection{Perubahan elemen fisik}

Sinkronik-diakronis merupakan metode yang digunakan untuk mengetahui asal muasal dan pengaruh-pengaruh yang menyebabkan terjadinya transformasi pada jalan umum di sekitar Bundaran Lungsir sehingga diketahui ilustrasi kronologis proses terjadinya transformasi fungsi jalan umum menjadi ruang publik di wilayah ini. Hal ini dilakukan dengan memetakan perubahan elemen fisik dan spasial yang membentuk citra visual ruas jalan umum di sekitar Bundaran Lungsir dari masa ke masa. Sebagai pembanding digunakan peta udara wilayah Bundaran Lungsir dari tahun 2001,2012,2014 dan 2016.

\section{Tahun 2001-2012}

Beberapa perubahan elemen fisik pada wilayah ini turut mempengaruhi perubahan citra kawasan. Adanya monumen budaya patung pengantin pepadun sebagai ikon/lanmark kota Bandar Lampung di Bundaran Lungsir menjadi daya tarik warga. Renovasi pada menara masjid dengan menambah ketinggiannya menjadikan menara dapat dilihat dari jarak yang cukup jauh, sehingga menjadi penanda sekaligus magnet bagi warga untuk datang dan melihat langsung.
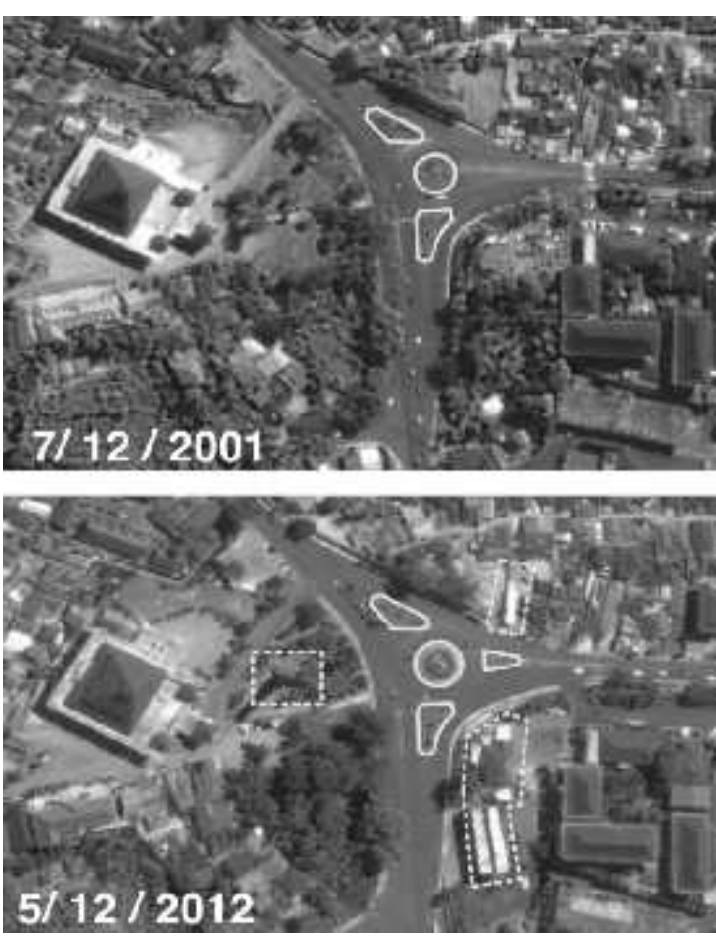

Gambar.7 Perbandingan foto udara wilayah Bundaran Lungsir tahun 2001 dan 2012

(Sumber : Olah studio dari Google Earth)

\section{Tahun 2014-2016}

Penambahan elemen air dan tata lampu pada bundaran dimana terdapat monumen budaya patung pengantin menambah keindahan dan meningkatkan citra visual kawasan dan secara langsung membuat wilayah Bundaran Lungsir menjadi ramai oleh warga yang datang untuk melihat, berfoto dan bersantai. Pada tahun-tahun ini transformasi Bundaran Lungsir menjadi ruang publik pada malam hari semakin besar. Jumlah warga yang datang semakin banyak, demikian juga jumlah pedagang yang mengadu untung.

Salah satu perubahan yang juga berpengaruh pada citra visual kawasan adalah dengan dibukanya halaman depan Masjid Al Furqan untuk taman dan ruang publik. Selain memberi visual yang lebih jelas pada wilayah Bundaran, taman publik ini juga memberi visual yang lebih jelas pada masjid AL Furqan itu sendiri sehingga memberikan identitas yang kuat bagi wilayah Bundaran Lungsir. 

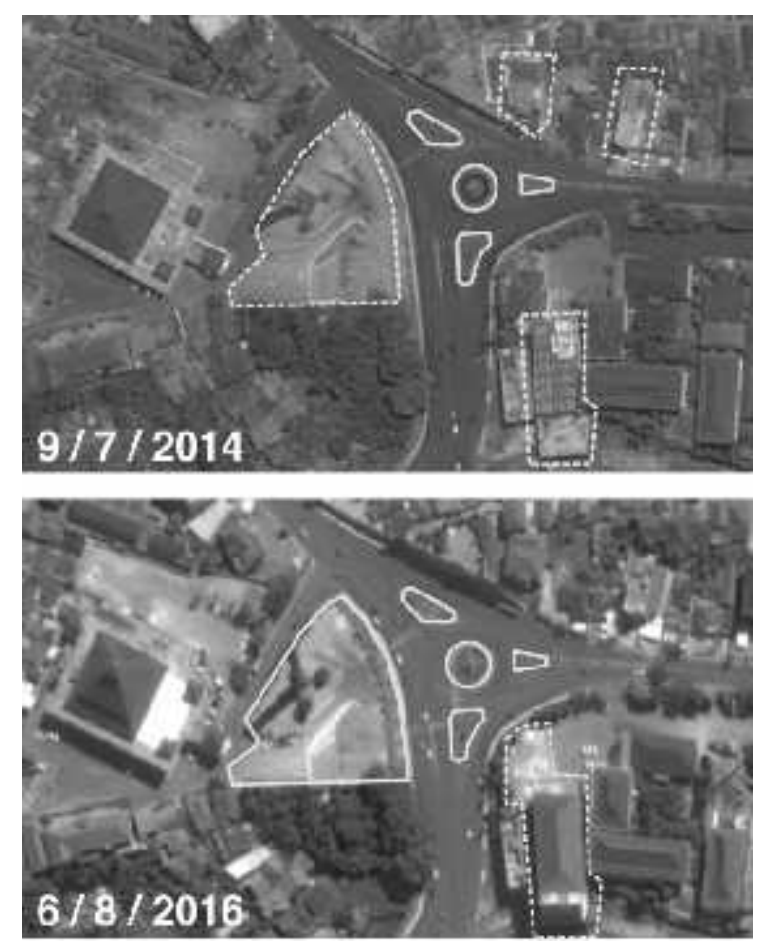

Gambar.8 Perbandingan foto udara wilayah

Bundaran Lungsir tahun 2014 dan 2016

(Sumber : Olah studio dari Google Earth)

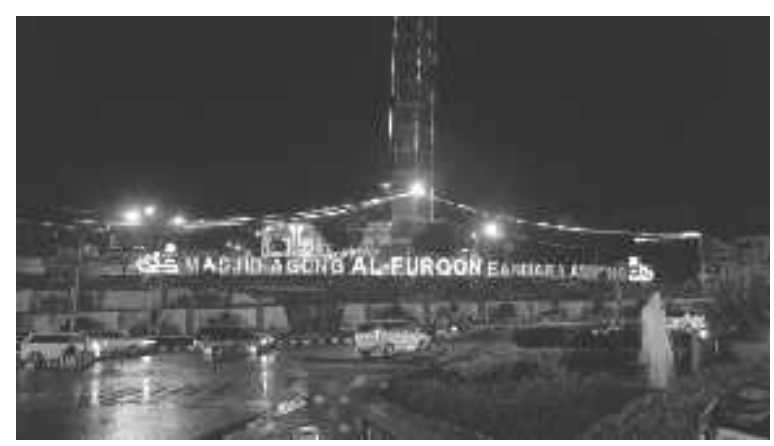

Gambar.9 Suasana malam hari Taman Masjid Al Furqan dilihat dari arah Bundaran (Sumber : wawailampungku.blogspot.com)

\subsubsection{Sebaran Pengguna}

Sebagai elemen non fisik yang menentukan arah transformasi ruang wilayah Bundaran Lungsir, maka perlu diketahui motivasi dan alasan warga memanfaatkan wilayah Bundaran Lungsir sebagai destinasi ruang publik.

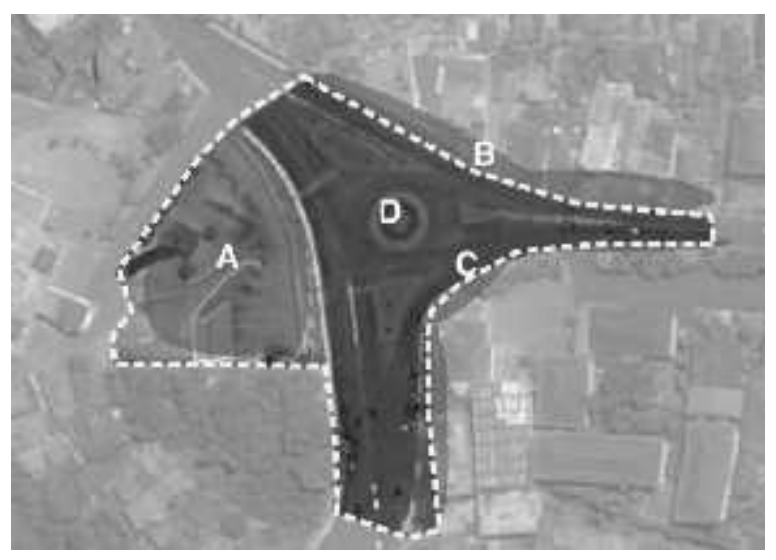

Gambar.10 Sebaran Zona berdasarkan sebaran pengguna pada wilayah Bundaran Lungsir

(Sumber: Olah studio dari Google Earth, 2016)

Metode kualitatif-eksploratif dilakukan dengan melakukan wawancara dan menyebar kuesioner. Untuk memudahkan pemetaan hasil, maka sebaran kuesioner dilakukan dengan membagi wilayah Bundaran Lungsir dalam beberapa zona berdasarkan sebaran pengguna di wilayah tersebut.

Untuk melihat rentang waktu kronologis terjadinya transformasi di wilayah Bundaran Lungsir menjadi ruang publik, maka perlu diketahui sejak kapan wilayah tersebut menjadi semakin ramai dikunjungi warga. Pedagang merupakan salah satu indikator adanya keramaian warga yang berrkumpul di satu tempat, sehingga perlu didata rentang waktu warga yang berdagang di wilayah tersebut. Pada kuesioner ditanyakan terhadap warga yang berdagang di wilayah Bundaran Lungsir terkait berapa lama mulai berdagang di wilayah tersebut. Hasilnya pada zona A, mayoritas pedagang memulai aktivitasnya sejak 4-6 tahun yang lalu sebesar 40\%, sedangkan pada zona B dan D mayoritas adalah 2-4 tahun sebesar $42 \%$ dan zona $\mathrm{C}$ pada 1-2 tahun sebesar $53 \%$.

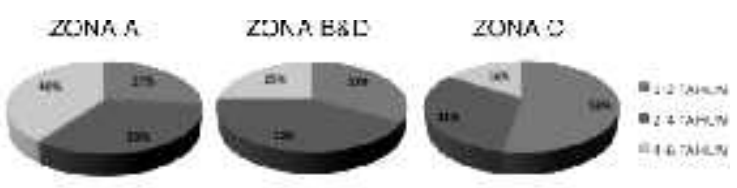

Gambar.11 Diagram Rentang Tahun Dagang (Sumber : Penulis, berdasarkan hasil kuesioner, 2016)

Jika dilihat rata-rata keseluruhan, maka mayoritas responden yaitu warga yang berdagang di wilayah tersebut memulai aktivitasnya sejak 2-4 tahun yang lalu sebesar 36\%, yang kedua terbanyak adalah pada 4-6 tahun lalu sebesar 35\% dan 1-2 tahun yang lalu sebesar 29\%. Dari data yang diperoleh diketahui bahwa warga mulai meramaikan wilayah bundaran Lungsir sebagai ruang publik berkisar 4 tahun terakhir. Adanya perbedaan prosentase terhadap rentang waktu dagang di tiap zona juga mengindikasikan pengaruh 
tempat terhadap aktivitas berdagang. Pedagang di Zona A bisa bertahan lebih lama disebabkan Zona A memang dirancang untuk taman/ ruang publik, sehingga secara desain lebih tertata dengan fasilitas penunjang yang lebih baik.

Analisa terhadap pedagang sebagai indikator rentang waktu kronoligis transformasi Wilayah Bundaran Lungsir didasarkan pada fakta bahwa munculnya pedagang sejalan dengan adanya keramaian dari kumpulan warga pada satu lokasi. Hal ini bisa dilihat pada hasil kuesioner terhadap alasan pedagang memilih berjualan di wilayah Bundaran Lungsir.
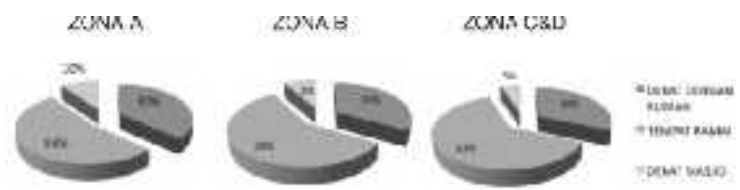

Gambar.12 Grafik alasan pemilihan lokasi dagang (Sumber : Penulis, berdasarkan hasil kuesioner, 2016)

Dari hasil kuesioner di zona A, B, C dan D, alasan terbesar responden kelompok pedagang (53\% pada Zona A, 58\% pada Zona B, dan $63 \%$ pada Zona $\mathrm{C}$ dan Zona D), memilih tempat berdagang di wilayah tersebut adalah karena adanya keramaian. Lebih lanjut alasan responden karena dekat dengan tempat tinggal sekitar 37\% pada Zona A, 34\% pada Zona B, dan $32 \%$ pada zona $\mathrm{C}$ dan $\mathrm{D}$, yang mengindikasikan bahwa rata-rata pedagang di wilayah Bundaran Lungsir ini merupakan warga sekitar. Sedangkan jumlah responden yang memilih alasan karena dekat dengan Masjid Al Furqan tidak lebih dari $10 \%$ pada tiap-tiap zona. Berdasarkan hasil Meskipun memberi karakter dan identitas visual yang jelas bagi kawasan, keberadaan Masjid Al Furqan ternyata bukan alasan utama para pedagang memilih berjualan di wilayah Bundaran Lungsir.

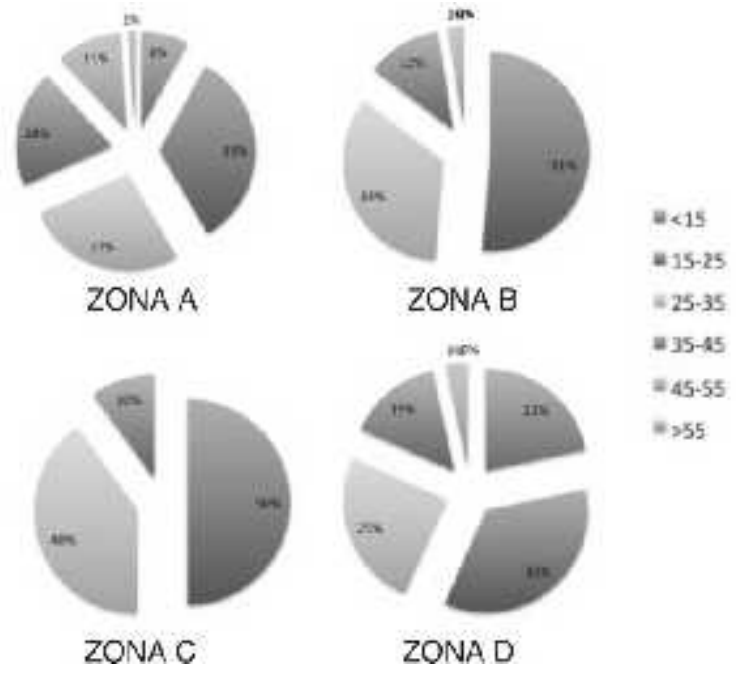

Gambar.13 Diagram Kelompok Usia Pengunjung pada Tiap Zona (Sumber : Penulis, berdasarkan hasil kuesioner, 2016)

Transformasi jalan umum di wilayah Bundaran Lungsir menjadi ruang publik perlu juga ditinjau dari sisi kriteria dan kualitas ruang publiknya. Ruang publik didefinisikan sebagai tempat yang aksesibel dan terbuka secara umum dimana masyarakat baik secara individu maupun kelompok dapat melakukan aktivitas di tempat tersebut. Sesuai dengan namanya maka suatu ruang publik harus terbuka terhadap setiap orang (Carr, 1992).

Gambar.13 menunjukkan diagram kelompok usia pengunjung pada tiap zona (Gambar .10), bahwa pada Zona B dan C yang berada di sisi jalan wilayah Bundaran Lungsir didominasi oleh pengunjung remaja kelompok usia 15-25 tahun yang prosentasenya mencapai $50 \%$. Sedangkan pada zona A dan D, kelompok usia pengunjung lebih beragam. Meskipun masih didominasi oleh kelompok usia 1535 tahun. Dari rentang usia pengunjung bisa dilihat bahwa transformasi wilayah Bundaran Lungsir menjadi ruang publik dapat dinikmati oleh berbagai usia. Tapi hanya pada zona A dan D yang dikunjungi oleh warga dengan rentang kelompok usia dibawah 15 tahun dan diatas 55 tahun.

Kualitas tempat akan mendorong vitalitas tempat tersebut apakah menarik untuk didatangi dan dikunjungi. Dalam kaitannya dengan ruang publik, kualitasnya dipengaruhi oleh beberapa aspek yaitu equity and acces (persamaan dan pencapaian), Variety (keberagaman), dan vitality (keberartian) yang menunjukkan keberagaman pengguna dan aktivitas yang dapat tertampung dalam ruang publik (Lynch, 1960). Pada kuesioner ditanyakan a lasan dari pengguna untuk datang ke Bundaran Lungsir. Hal ini bertujuan untuk melihat seberapa besar kualitas dari Bundaran Lungsir sebagai ruang publik.

Hasil dari kuesioner memperlihatkan bahwa $44 \%$ responden memilih alasan utama untuk datang berkunjung ke Bundaran Lungsir adalah pesona keindahan tempat tersebut (Gambar.14). Hal ini menunjukkan bahwa perubahan elemen fisik pada wilayah ini berpengaruh terhadap keinginan warga untuk datang. Lebih lanjut sebanyak $28 \%$ responden kelompok pengguna memilih akses sebagai alasan utama datang ke Bundaran Lungsir. Sebagai persimpangan jalan-jalan utama kota Bandar Lampung, wilayah Bundaran Lungsir memiliki keuntungan mudah dijangkau baik dengan kendaraan pribadi maupun angkutan umum. 


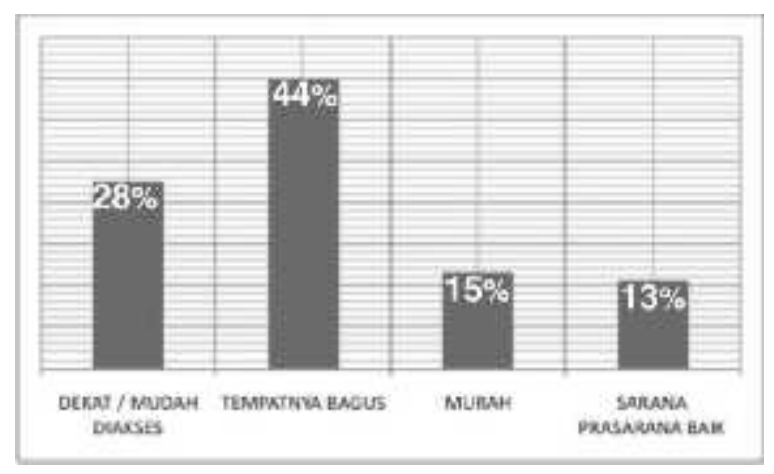

Gambar.14 Grafik alasan responden berkunjung (Sumber : Penulis, berdasarkan hasil kuesioner, 2016)

Selain itu alasan akses yang dekat dari rumah tinggal memperlihatkan indikasi warga sekitar yang banyak memanfaatkan wilayah ini sebagai ruang publik. Sebanyak 15\% responden pengunjung memilih murah sebagai alasan utama datangn ke Bundaran Lungsir. Sebagai ruang jalan yang bertransformasi menjadi ruang publik, wilayah ini gratis dan terbuka untuk semua warga. Variasi makanan dan minuman yang dijajakan juga relatif terjangkau, sehingga banyak warga yang memilih ke wilayah ini untuk sekedar bersantai dan kumpul bersama. Hanya $13 \%$ responden yang memilih sarana prasarana di wilayah ini sudah baik sebagai alasan utama datang berkunjung. Hal ini bisa dimaklumi mengingat pada hakikatnya, wilayah ini merupakan ruang jalan yang tidak didesain sebagai ruang publik, sehingga sarana dan prasarana yang ada tidaklah terlalu mendukung kegiatan ruang publik.

Hasil kuesioner digambarkan dalam diagram Gambar.15, yang menunjukkan ada empat aktivitas utama yang dilakukan pengunjung. Pada Zona A dan $\mathrm{D}$ dimana mayoritas pengunjung berusia 15-25 tahun aktivitas pacaran adalah yang dominan. Pada Zona $\mathrm{B}$, meskipun rentang usia dominan pengunjung juga antara 15-25 tahun, tapi $44 \%$ responden datang ke Bundaran Lungsir untuk berkumpul dengan teman/keluarga. Demikian pula di Zona C, 34\% responden datang untuk berkumpul bersama teman dan keluarga.

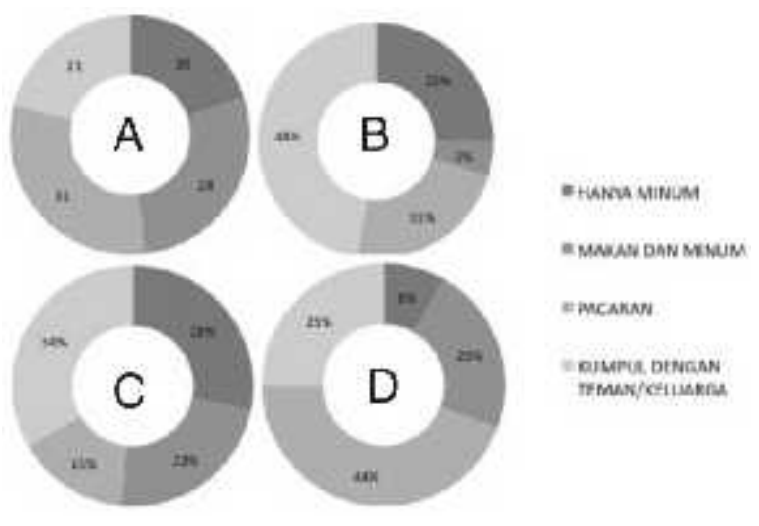

Gambar.15 Diagram Aktivitas Utama Pengunjung (sumber: Penulis berdasarkan hasil kuesioner, 2016)

Sebagai ruang publik wilayah Bundaran Lungsir didominasi aktivitas pacaran dan berkumpul bersama teman/keluarga. Sesuai dengan dominasi usia pengunjung ke wilayah ini yang merupakan warga usia muda. Sebagai ruang publik yang diminati, wilayah Bundaran Lungsir mampu memberikan karakter yang kuat akan vitalitasnya sehingga dikunjungi warga. Hal tersebut tercermin dari seberapa sering responden pengunjung untuk datang dan menikmati ruang publik di Bundaran Lungsir tersebut.

Hasil kuesioner menunjukkan bahwa $60 \%$ responden kelompok pengunjung datang ke Bundaran Lungsir sebanyak 3-6 kali dalam sebulan, dan beberapa responden bahkan mengunjungi tempat ini lebih dari 12 kali dalam sebulan. Hal ini mengindikasikan bahwa ruang publik yang tercipta di wilayah ini sebagai bentuk transformasi fungsi ruang jalan, mendapat apresiasi dari warga untuk mengunjunginya kembali berulang kali.

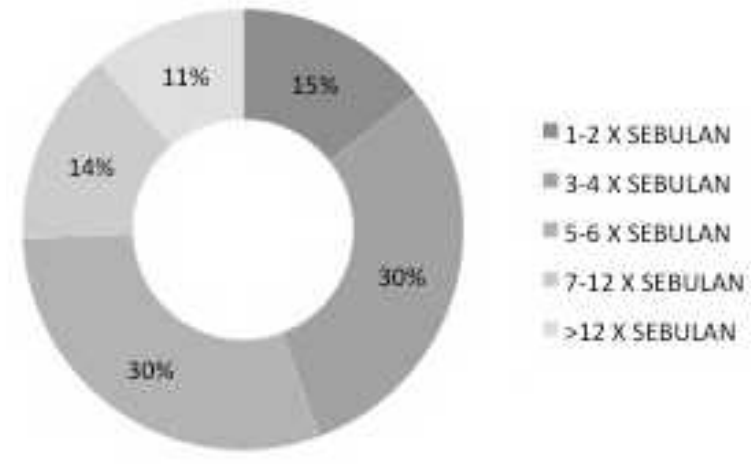

Gambar.16 Diagram Frekuensi Kunjungan (sumber: Penulis berdasarkan hasil kuesioner, 2016)

\subsection{Hasil Penelitian}

Bundaran Lungsir memiliki karakter visual yang cukup kuat. Adanya Monumen Budaya Patung Pengantin, serta Masjid Agung Al Furqon memberi identitas yang jelas bagi kawasan ini secara keseluruhan. Secara spasial ruang jalan, Bundaran Lungsir memiliki dimensi dan skala ruang yang besar, sehingga elemen-elemen fisik pada wilayah ini dapat terlihat jelas. Faktor dimensi dan skala ini juga mengaburkan kesan meruang yang kemudian menjadi ciri khas dan membedakan ruas jalan di wilayah Bundaran Lungsir ini dibandingkan dengan ruas jalan lain di Kota Bandar Lampung. Adanya ciri karakter visual yang kuat berperan besar dalam membentuk suatu wilayah/tempat menjadi destinasi bagi warga kota untuk datang dan berkunjung. 


\section{KESIMPULAN DAN SARAN}

\subsection{Kesimpulan}

1) Transformasi fungsi jalan umum menjadi ruang publik sebagai ruang spatiotemporal dalam konteks skala urban pada dasarnya terbentuk dari kebutuhan warga/masyarakat akan ruang untuk berinteraksi, melakukan aktivitas fungsional dan ritual dalam suatu ikatan komunitas, ataupun individu.

2) Elemen fisik sebagai pembentuk karakter visual ruang spasial di Bundaran Lungsir merupakan faktor dominan yang mendorong terjadinya transformasi fungsi. Perubahan-perubahan elemen fisik pada wilayah tersebut kemudian menjadi ikon/lanmark yang menjadi magnet bagi warga untuk datang dan beraktivitas.

3) Adanya aktivitas akan mendorong permintaan akan sarana dan prasarana untuk menunjang aktivitas itu sendiri, yang kemudian menjadi permasalahan Bundaran Lungsir, karena pada hakikatnya penggunaan/pemanfaatan ruang yang terjadi tidak sesuai dengan fungsi aslinya sebagai ruang jalan dan sirkulasi lalu lintas umum.

\subsection{Saran}

Dalam mempertahankan fungsi ruang publik pada Bundaran Lungsir, mengingat potensi yang dimilikinya, perlu dibarengi dengan regulasi penataan yang jelas terkait fungsi dan peruntukan area serta bangunan di sekitar wilayah Bundaran Lungsir, karena ruang publik menjadi hal yang penting bagaimana suatu kota dinilai baik, yang juga mencerminkan kondisi masyarakat/ warga yang menghuninya.

\section{DAFTAR PUSTAKA}

Attoe, Wayne. Logan, Donn; "American Urban Architecture, Catalyst In The Design of Cities" ; University of California Press; 1989

Carmona, Matthew. Heath, Tim. Oc, Taner. Tiesdell, Steven. 2003. "Public Places-Urban Space": Architectural Press.

Carr,Stephen, et al.; "Public Space"; Cambridge University Press; 1992

Ching, Francis D.K. Architecture : "Form, Space And Order"; Van Nostrand Reinhold Company. New York; 1996.

Habraken, N.J ; " The Structure of The Ordinary" ; MIT Press; 1998
Jencks, Charles. Kropf, Karl ; "Theories And Manifestoes Of Contemporary Architecture" ; Wiley-Academy; 1997

Jiang, Shan. Ferreira, Joseph. Gonzales, Marta C.; "Discovering urban spatial-temporal structure from human activity patterns" : Association for Computing Machinery (ACM); 2012

Madanipour, Ali; "Design of Urban Space, An Inquiry Into A Socio-spatial Process” ; Wiley; 1996

Trancik, Roger; "Finding Lost Space, Theories of Urban Design” ; Van Nostrand Reinhold Company; 1986 